\title{
Correction to: Magnetic Characterization of Ferromagnetic Shape Memory Components Under Defined Mechanical Loading
}

\author{
Fabian Ehle $^{1}$ (D) Peter Neumeister $^{1,2}$ (D) $\cdot$ Eric Haufe $^{1} \cdot$ Holger Neubert $^{1}$ (D)
}

Published online: 22 April 2021

(C) ASM International 2021

\section{Correction to: \\ Shape Memory and Superelasticity (2020) \\ 6:10-23 https://doi.org/10.1007/s40830-020- 00266-2}

The article "Magnetic Characterization of Ferromagnetic Shape Memory Components Under Defined Mechanical Loading", written by Fabian Ehle, Peter Neumeister, Eric Haufe, and Holger Neubert was originally published electronically on the publisher's internet portal on 29 January, 2020 without open access. With the author(s)' decision to opt for Open Choice the copyright of the article changed on 08 April 2021 to (CThe Author(s) 2020 and the article is forthwith distributed under a Creative Commons Attribution 4.0. International License, which permits use, sharing, adaptation, distribution and reproduction in any medium or format, as long as you give appropriate credit to the original author(s) and the source, provide a link to the Creative Commons License, and indicate if changes were made. The images or other third party material in this article are included in the article's Creative Commons License, unless indicated otherwise in a credit line to the material. If material is not included in the article's Creative Commons License and your intended use is not permitted by statutory regulation or exceeds the permitted use, you will need to obtain permission directly from the copyright holder. To view a copy of this license, visit http://creativecommons. org/licenses/by/4.0/.

The original article has been corrected.

Publisher's Note Springer Nature remains neutral with regard to jurisdictional claims in published maps and institutional affiliations.
The original article can be found online at https:// doi.org/10.1007/s40830-020-00266-2.

\section{Fabian Ehle}

fabian.ehle@ikts.fraunhofer.de

1 Fraunhofer IKTS, Fraunhofer Institute for Ceramic Technologies and Systems, Dresden, Germany

2 Present Address: Eberswalde University for Sustainable Development, 16225 Eberswalde, Germany 